\title{
Encantadoras do mundo: outro olhar sobre o feminino na trilogia Coração de ouro de Lars von Trier \\ Larissa Malfatti Vieira Corilow ${ }^{1}$ \\ DOI 10.20396/eha.vil4.3474
}

\section{Introdução}

Autor de uma filmografia desconfortável e desconcertante, o cineasta dinamarquês Lars von Trier, parece ser mais lembrado pelas polêmicas ${ }^{2}$ exploradas midiaticamente do que por um exame realmente atento à sua obra. Contudo, numa breve análise à sua filmografia, não é difícil perceber a tensão entre seu lugar de enunciação e a constante figuração do feminino que flui, no entanto, do imaginário masculino. Exceto por alguns filmes - como os da trilogia Europa ${ }^{3}$, The Boss of it all (2006) e seu último The house that Jack built (2018) - se destacam, ao longo de sua carreira, não apenas em número, mas também pela pungência das temáticas evocadas, o protagonismo feminino.

Essa constante figuração do feminino, despertou críticas ferrenhas ao filme Anticristo (2009) que em meio ao Festival de Cannes foi tido como um filme de ódio às mulheres, rendendo ao diretor a qualidade de misógino ${ }^{4}$. Contudo, afastando-se de sua recepção internacional, circunscrevendo essa obra ao interesse acadêmico sobre o tema, a tese Penetrando o Éden: Anticristo, de Lars von Trier, à luz de Brecht, Strindberg e outros elementos inquietantes $(2016)^{5}$, oferece uma compreensão alternativa e análoga a que Coli, anunciara em sua coluna na Folha de São Paulo à época: "Vários críticos condenaram, ou assinalaram, a misoginia em von Trier. No entanto, a situação exposta não o confirma"6.

\footnotetext{
1 Mestra em Sociologia pela Universidade Estadual de Campinas (IFCH - Unicamp). Pesquisa financiada pelo Conselho Nacional de Desenvolvimento e Tecnológico.

2 Do banimento do Festival de Cannes por sete anos, causada por uma fala interpretada como tendo conteúdo de apologia nazista: "- I am a nazi". Em 2018 von Trier retorna ao festival, novamente de modo intranquilo, com massivas debandadas durante a exibição de seu último filme The house that Jack built. Recebido apaticamente pela crítica jornalística, no entanto, desbancou Anticristo (2009) do hall de mais misógino de sua carreira para o segundo lugar.

3 Composta pelos filmes Elemento of crime (1984), Epidemic (1987) e Europa (1991).

4 Anticristo (2009), receberia um antiprêmio do júri em Cannes, por ser o "filme mais misógino de Lars von Trier".

5 KRUGER, Patrícia de Almeida. Penetrando o Éden: Anticristo, de Lars von Trier, à luz de Brecht, Strindberg e outros elementos inquietantes. São Paulo, Doutorado, Universidade de São Paulo / Programa de pós-graduação em estudos linguísticos e literários em inglês da Faculdade de Filosofia Letras e Ciências Humanas, 2016

6 Coli, Jorge. Sexo, luto e martírio. Folha de S. Paulo, São Paulo Coluna ponto de Fuga, Caderno mais, coluna Ponto de fuga, 25/10/2009. Disponivel em: <https://www1.folha.uol.com.br/fsp/mais/fs2510200904.htm>. Acessado 19/12/2019
} 
Inaugurada com Breaking the waves $(1996)^{7}$, seguida por Os idiotas (1998) ${ }^{8}$ e encerrada por Dançando no escuro $(2000)^{9}$, a trilogia Coração de ouro, obra pregressa à polêmica de Cannes, não desfrutou de uma recepção menos tensa em relação a política de gênero. Tendo revelado o intuito de tratar sobre o tema da bondade ${ }^{10}$, a partir dessas obras, o cineasta dessa vez foi chamado de macho clichê, pois reproduziria valores patriarcais que associaram a bondade ao papel social feminino, reproduzindo lugares comuns machistas. Posição reiterada por parte da crítica, sobretudo acerca de Bess a protagonista de Breaking the waves.

É inegável que Bess esteja inserida num contexto absolutamente patriarcal, e seja alvo da misoginia no contexto ficcional do filme. Mas ao ter a obra como objeto e não a biografia de von Trier, chega-se uma conclusão diferente dessa e também à compreensão de que a análise da obra não doa sentido para decidir se seu diretor é ou não machista, ou misógino, sendo que ao partir a análise da obra, pode-se chegar a uma conclusão diferente e que nada revela sobre o próprio diretor.

Ao direcionar o olhar não somente às protagonistas da trilogia Coração de ouro, mas também às coadjuvantes, igualmente capazes de informar sobre o significado da composição do imaginário trieriano, percebe-se que a unidade de afeto, de cuidado e humanização é sempre acentuada através de uma figura feminina. Em Breaking the waves, é somente através de Dorothy-carinhosamente

7 O filme nos mergulha no cotidiano "gélido" de uma comunidade protestante da Escócia, que exercita sua fé numa religiosidade dura, de matizes austeras e desencantadas, dominada por intérpretes masculinos, essa ordem será, no entanto, perturbada por uma mulher. A protagonista Bess desafiará os parâmetros de sua "comunidade" através de sua doçura e amizade terna que trava com Dodo, e também ao se entregar intensamente ao prazer erótico com o marido, o outsider Jan, um operário de uma plataforma de petróleo, que não compartilha da fé local. Após uma idílica lua de mel, Jan tem de retornar ao trabalho e Bess fica num estado emocional que é condenado por todos como excessivo. Ao fazer uma prece pedindo para que o marido retorne antes do esperado, Jan voltará, contudo, como vítima de um acidente que o deixa a beira da morte e tetraplégico. Nesta situação ele decide que sua esposa deve desligar-se dele e procurar amantes que o substituam, como Bess se ofende com o pedido, Jan tenta contornar essa recusa a fim de "libertá-la", pautado no caráter abnegado de Bess, ele diz que a busca por um amante era para o bem dele então, e não para o dela, como ele havia dito anteriormente, sugerindo que as experiências sexuais vividas por ela com outros homens o manteriam vivo. Bess cede ao pedido, por causa das ambíguas melhoras que Jan apresenta durante seu martírio sexual.

8 Um grupo de homens e mulheres vivem juntos numa casa onde o propósito é "liberar o idiota que existe dentro de cada um", eles interpretam deficientes mentais em público, utilizam os benefícios destinados a pessoas que realmente tem deficiência, se livram de pagar contas e ganham dinheiro fácil através de suas encenações.

9 Selma ocupa um papel eminentemente marginal na sociedade estadunidense, imigrante eslovena, sofre de uma doença genética que também afetará Cene, seu filho, causando-lhe cegueira progressiva. Selma mora com o filho pré-adolescente num trailer alugado situado no mesmo terreno da casa de Linda e Bill, família americana de classe média altamente seduzida pelo desejo de consumo e elevação de seus status sociais, está, no entanto, afundada em dívidas. Selma trabalha numa fábrica de chapas metálicas, juntando todos os escassos recursos para pagar uma cirurgia oftálmica para que Gene não perca a visão como ela, à medida que a quantia chega perto do suficiente Selma vai ficando cada vez mais "no escuro". O policial Bill vê nessa fragilidade uma oportunidade de adiar seus problemas com o banco, entra no trailer ainda na presença de Selma, que cega não o percebe, então ele saqueia as suadas economias dela. Ao perceber que a poupança havia sumido, Selma prontamente entende o que aconteceu, com justeza vai pegar de volta a quantia com Bill que, no exato momento, está contando o dinheiro roubado, enredando a esposa numa trama de mentiras sobre Selma diz que ela teria tentado seduzi-lo, enganando também a esposa, ele finge uma briga com Selma, dando a entender que ela não aceitasse sua "recusa amorosa" e estivesse ficando violenta, contudo, é ele quem Ihe aponta uma arma. Selma confusa, agora com a arma em punho fecha os olhos e atira na direção de Bill, que só solta o dinheiro depois de ser duramente ferido pela mala de dinheiro que ele levaria ao banco. A aparente torpeza do crime de Selma, que golpeia Bill repetidas vezes, até partir seu crânio, rende-lhe a sentença de morte por enforcamento, da qual ela pouco se defenderá, resguardando à família de Bill sua memória, não revelando o que de fato aconteceu, pois havia prometido a Bill, seu amigo, não contar.

10 Em nota introdutória ao roteiro de Breaking the waves, von Trier afirma: "This movie is about 'good", colocando o termo entre aspas. TRIER, Lars von. Breaking the waves. United Kingdon: Faber and faber, 1996. (p.20) 
chamada de Dodo - que Bess recebe um olhar humano, que acomuna ao invés de condenar e separar, Dodo e Bess são cúmplices e iguais, se acolhem numa amizade intensa, enquanto todos os outros personagens da narrativa violam a humanidade de Bess. (Fig. 1)

Também em Dançando no escuro, é o olhar feminino que humaniza, o afeto que nos é oferecido novamente em primeiríssimo plano, como no primeiro filme, é agora reiterado na trilogia a partir da amizade de Kathy e Selma, belamente marcado na cena de grande intensidade emocional na qual as amigas vão ao cinema assistir a um musical, gênero favorito de Selma, mas ela, já praticamente cega, só participa da exibição pelo cuidado de Kathy, que pega a palma de sua mão e recompõe com os dedos os passos de dança projetados na tela, o gesto é selado com um beijo de Kathy nas mãos de Selma. (Fig.2)

Ainda em Dançando no escuro, é novamente feminina a companhia que torna o horror da espera pela morte na penitenciária de segurança máxima algo menos insuportável para Selma: é a guarda Brenda que se identificando instantaneamente com a experiência da maternidade se solidariza e ampara Selma, sendo a única forma de humanidade experimentada por ela à caminho de sua execução por enforcamento.

Esse papel "acomunador", também estaria sinalizado na fábula Coração de ouro"1 , resgatada de uma memória infantil, citada por Trier como fonte de inspiração ${ }^{12}$, que daria nome à trilogia em questão. É notável na história da menina órfã a articulação de uma ética de profunda identificação com o outro, com o qual se divide não apenas o "excedente", mas também aquilo que fará falta, curiosamente o único critério para a entrega é a evidência da necessidade do "outro", que se apresenta a Coração de Ouro com uma urgência superior as suas próprias, embora a menina sofra do mesmo tipo de pauperização. Aqui a ética fraternal se impõe e triunfa sobre a inevitabilidade da ne-

\footnotetext{
11 No original Culd hjerte. "Há muito tempo, numa imensa floresta havia uma pequenina casa solitária. Naquela casa vivia uma menininha. A menininha era tão delicada e gentil que as pessoas a nomearam de Coração de Ouro. Mas Coração de Ouro era pobrezinha e sozinha no mundo. Ela não tinha nem mãe nem pai. O fogo na lareira estava quase se apagando e o único alimento que tinha era um pequenino biscoito. Diante disso, Coração de ouro saiu da pequena casa e começou a vaguear. Com um pedacinho de biscoito numa mão e uma bengala na outra, ela andou muito pela imensa floresta. Foi quando ela encontrou uma senhora, que estava com uma terrível fome. Coração de Ouro não hesitou e deu à velha seu biscoito. 'Tome meu biscoito', disse. 'Eu ficarei bem'. Aí veio vagando ao longe um andarilho bem velho e cansado. 'Pegue minha bengala para o senhor se equilibrar”, disse Coração de Ouro, 'Não importa o que aconteça, eu ficarei bem'. Quando a noite chegou, Coração de ouro estava cansada, deitou-se no chão da floresta para tirar um cochilo. 'Eu me sinto um pouco só', disse, 'mas farei minhas orações à noite, e ficarei bem'. No dia seguinte Coração de Ouro vagueou e encontrou uma garotinha pobre, cujas orelhas estavam geladas de frio. Então Coração de Ouro Ihe deu seu chapéu. 'Tome meu chapéu, disse. Eu ficarei bem'. Numa ponte, Coração de ouro encontrou um menino aos trapos. Ele estava congelando de frio porque não tinha casaco. Foi então que Coração de Ouro lhe deu seu casaco. 'Tome o meu casaco, eu ficarei bem', disse. Agora Coração de Ouro não tinha praticamente nada para doar. Ela estava totalmente pobre.

Mas numa noite algo especial aconteceu. As estrelas caíram do céu e encontraram Coração de Ouro. Todas as estrelas que via se transformavam-se em dinheiro. Um sorriso brilhante iluminou seu rosto. 'Eu ficarei bem', ela disse. Num certo dia um lindo príncipe apareceu e pediu que Coração de Ouro se casasse com ele: 'Eu sou o menino da ponte a quem você deu o seu casaco, seu coração é feito de pura bondade, e por isso você será minha princesa', disse. 'Tome meu coração', disse Coração de Ouro, 'E eu ficarei bem'. (apud Cerace, 2006: 33-34) 12 Trier, 1996 apud Lumholdt, Lars von Trier interviews. Mississippi: The University Press of Misisippi, 2003. (p.109)
} 
cessidade objetiva, não é "a mão invisível" do liberalismo econômico que dita os ânimos na fábula.
A gênese das personagens da trilogia Coração de ouro a partir de
Bess de Breaking the waves

A partir da análise de elementos internos a narrativa de Breaking the waves e do exame das influências artísticas que poderiam se relacionar com a elaboração do imaginário que dá origem às protagonistas de Coração de ouro, chega-se à conclusão de que a figura feminina ali, não é apenas contestadora da ordem patriarcal - caso de Bess no contexto onde a personagem é inserida - mas também é uma intérprete privilegiada do mundo moderno, expondo fraturas em seu discurso organizado, onde se manifesta mais pesadamente o impasse da bondade, já que as personagens de Coração de ouro, Bess e Selma são mortas mesmo diante de sua intensa docilidade.

O outro passo consistiu numa arqueologia da personagem, onde foram buscadas referências estéticas e temáticas em outros filmes do contexto escandinavo que me permitissem entender a gênese de Bess. O tema do desencantamento religioso foi percebido também em Ordet (1955) do cineasta Carl Theodor Dreyer, que é um cineasta bastante apreciado por von Trier.

Em Ordet, aprofundam-se duas versões do cristianismo, um desencantado e patriarcal, ou outro encantado, louco, feminino e infantil, fazendo frente também aos dogmas modernos da racionalidade: os melhores intérpretes da fé e do mundo são os marginalizados desse contexto social, o "doente mental" Johannes que na verdade é o mais lúcido, a mulher e mãe Inger, fora da esfera pública e a criança, que ainda pode crer de forma sincera. Numa quase síntese da mulher, do louco e da criança, a compreensão da composição do imaginário que inspira Bess se dá através de analogias temáticas e estéticas entre essas obras. Inclusive através de semelhanças estética entre Bess e Inger, observáveis ao comparar as duas obras (Fig.4-7)

Assim, as personagens de Coração de ouro estariam mais próximas de uma recorrente figura dramática no cinema europeu: a holy fool figure (figura do idiota sagrado, ou idiota de Cristo). ${ }^{13}$

Em Breaking the waves, Bess não apenas desafia a ordem patriarcal, como é intérprete privile-

\footnotetext{
13 "A holy fool figure, cumpriria uma dupla função crítica: ao mesmo tempo como críticos do vazio espiritual e totalitário das ideologias que devastaram a Europa central e oriental ao longo do século passado e refletindo sua versatilidade como forma de comentar sobre inconsistências e fraturas no discurso da racionalidade moderna. O idiota frustra a lógica convencional se mantendo fora da linguagem organizada. Essa reflexão explica como a loucura e a idiotice podem ser parte de uma estratégia comum já que ambas são maneiras de transgredir os sistemas de racionalidade organizadas, seja ele social, religioso, político ou linguístico. O uso do "idiota" expõe problemas da modernidade". BIRZACHE, Alina G. The holy fool in European cinema. London and Newyork: Routledge, 2016.
} 
giada nela, a partir de sua sensibilidade, só ela é capaz de trazer mecanismos de crítica à fé racionalizada de seu vilarejo. Ela que não pode sequer falar durante os cultos de sua igreja, no entanto, trará elementos de uma teologia renovada, sendo melhor intérprete religiosa do que a ala masculina, ela teologizará no lugar dos homens, ocupando um espaço eminentemente masculino. Isso é observável na narrativa, especialmente quando saindo de um culto, Bess declara: "It is stuped that only man can talk in the service. I think God never said that" ${ }^{14}$.

Olhando para o filme a partir das acepções duas do conceito weberiano de desencantamento do mundo $0^{15}$, percebeu-se nele dois universos narrativos absolutamente opostos e em tensão. De um lado temos um universo desencantado e do outro "encantado" representado por Bess. Fazem parte do primeiro a igreja e a comunidade médica do filme que sugerem a eutanásia de Jan, e o próprio Jan, para quem a vida perde o sentido quando o corpo biológico (matéria) já não oferece elementos pra desfrutar a vida, ao contrário de Bess atribui sentido transcendente à vida do marido.

A fé racionalizada da igreja foram associadas as seguintes semelhanças com o perfil protestante traçado por Weber, em A ética protestante e o espírito do capitalismo: descrença na possibilidade de milagres; é puritana e despreza universo erótico; compreende o matrimônio como exercício de vocação desapaixonada para a procriação de filhos; despreza todo excesso de sentimento: "tendo uma posição absolutamente negativa perante todos os elementos de ordem sensorial e sentimental na cultura da religiosidade"(Weber, 2004:96); falta de interesse artístico e supressão de elementos festivos como o sino; total austeridade nas cerimônias fúnebres, sem canto ou hino; profundo isolamento interior; frieza e severidade nas relações, e condena até mesmo os laços intensos de amizade, concebido como "ato irracional inapropriado para a criatura, pois competiria com a glória devida à Deus; impessoalidade no exercício do amor ao próximo e atrofia da humanidade nas relações com 0 próximo (Weber, 2004:210). A forma como a personagem de Bess é forjada no interior da narrativa

\footnotetext{
14 "É uma estupidez que somente homens possam falar durante o culto. Eu penso que Deus nunca disse isso" (Minha tradução. Extraído do filme)

15 Segundo Weber, o desencantamento do mundo, não ocorre por causa de um avanço da ciência que expulsaria a validade do universo religioso para explicar o mundo. Ao contrário, o processo de racionalização daria seu início dentro do universo religioso, a partir do judaísmo, portanto, através das religiões de matriz cristã, ao fundar uma metafísica religiosa, a ideia de um Deus supramundano e uno, que não pode ser coagido a nos responder de acordo rituais mágicos, mas que observaria uma conduta ética, seus humores não são alterados facilmente como é próprio da mitologia, a ideia de que Deus é uma unidade intelectual centrada que não está no vento, no mar, ou nos astros como era próprio do animismo. A matriz cristã racionalizaria a experiência no mundo assim, retirando os elementos mágicos da crença. Por outro lado, o desencantamento promovido pela ciência, que é correlato e paralelo ao desencantamento religioso é aquele que retira o sentido do mundo, baseado no escritor Russo Tolstói, Weber dirá que a ciência não consegue responder à indagação que realmente importa: "que devemos fazer? Como deveremos viver?" Nos tempos modernos, portanto, andariam juntos a ciência e a falta de sentido, o conhecimento científico propriamente dito se exercita sem confiar em qualquer fim último ou valor eterno. Portanto, o cristianismo desmagifica o mundo e o enche de sentido, significados éticos e transcendentes, e a ciência por seu turno retira o sentido do mundo sem colocar nenhuma esfera de sentido no lugar. Ela retira o sentido do mundo e não é capaz de substitui-lo por outro. PIERUCCI, Antônio Flávio. O desencantamento do mundo: todos os passos do conceito em Max Weber. São Paulo: Editora 34, 2013. (p.159)
} 
de Breaking the waves se contrapõe, ou mesmo desafia, cada um destes parâmetros da igreja local.

Bess se contrapões ao elevado puritanismo sexual e condenação do erótico e à compreensão do matrimônio como exercício de vocação desapaixonada para a procriação de filhos. O olhar sobre o erótico de um dos precursores da Reforma Agostinho ${ }^{16}$ e do reformador Lutero ${ }^{17}$ é, portanto, completamente incompatível com a forma como Bess entende e experimenta o erótico. Não só por gozá -lo intensamente, mas por iniciá-lo ansiosamente, ainda na festa de seu casamento. Considerando o cultivo da esfera do prazer como algo compatível com o divino, como dádiva e não através da ótica reprodutora, ou seja, da vocação desapaixonada por fazer filhos. O que é observável quando, satisfeita após ter se relacionado com Jan, Bess faz uma oração: "eu te agradeço por me conceder o maior dom de todos, te agradeço pelo dom do amor, agradeço por Jan. Bess não divide o erótico e o fraterno, ambos os amores são compatíveis e dignos de gratidão, o casamento é uma dádiva e não um "mal menor". Aqui a própria personagem imprimi sua teoria sobre o "amor".

A falta de interesse artístico e supressão de elementos festivos como o sino, também é contestada por Bess que é a repositora deles, não só no epílogo através dos enormes e barulhentos sinos que a homenageiam, mas ao longo da narrativa ela declara: "I like church bells! Lets put them back"18 $^{\prime 18}$

Frieza e austeridade nas relações, condenação até mesmo das relações de amizade, impessoalidade no exercício do amor ao próximo e atrofia da humanidade nas relações com o próximo, por sua vez estão na mais completa contramão da intensa amizade vivida por Bess e Dodo, onde elas se acolhem, tornando o que é frio em caloroso, passam pelo sofrimento juntas, é o oposto completo de uma relação de amizade pouco sentimental.

Sendo mulher e não tendo lugar de fala, ela faz seu primeiro e último discurso, num momento em que se qualifica como intérprete, capaz de comunicar algo que a comunidade religiosa masculina do filme já não está sensível : "You can not be in love with a word, you can only be in love with another human being, that is perfection!"19

\footnotetext{
16 Santo Agostinho dizia no seu tratado sobre o casamento e a concupiscência, De Nuptiis et Concupiscentia" (Cavalcanti, 2005:202): "Se os dois cônjuges a isso se entregam [ao prazer na união sexual], não merecem o nome de esposos; e se, desde o início, assim se buscaram, não é para o casamento que se uniram, mas para entregarem-se à fornicação. [...] Ouso dizer: ou aquele que assim procede é, de certa maneira, a prostituta de seu marido, ou este é o adultero de sua mulher." (Agostinho apud Cavalcanti, 2005:202)

17 Acerca do casamento, dizia Lutero: “'mal menor, para evitar a fornicação e a necessidade, por parte de Deus, de 'passar por cima' deste pecado legítimo, sendo ele a consequência da insuperabilidade absoluta, criada pelo pecado original, da concupiscência”.

18 Eu gosto de sinos! Vamos colocá-los de volta! (Minha tradução)

19 "Você não pode se apaixonar por palavras, você só pode se apaixonar por outro ser humano, isso é perfeição!" (Minha tradução, extraído do filme).
} 


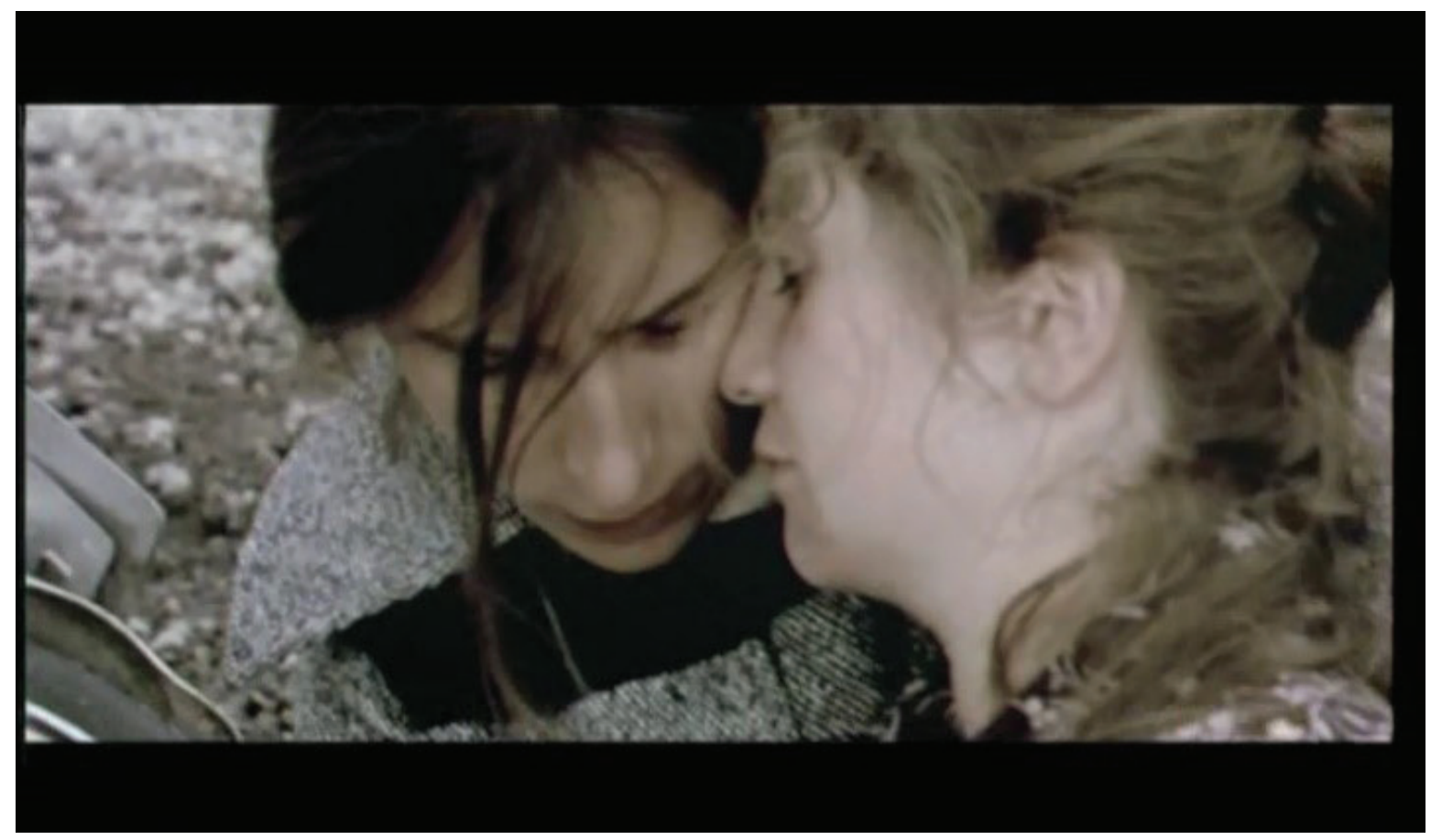

[Figura 1] Primeiríssimo plano, normal, 3/4. Dodo e Bess se acolhem intensamente, depois que Bess é agredida sexualmente, apedrejada por crianças e ignorada pelo pastor que não a socorre.

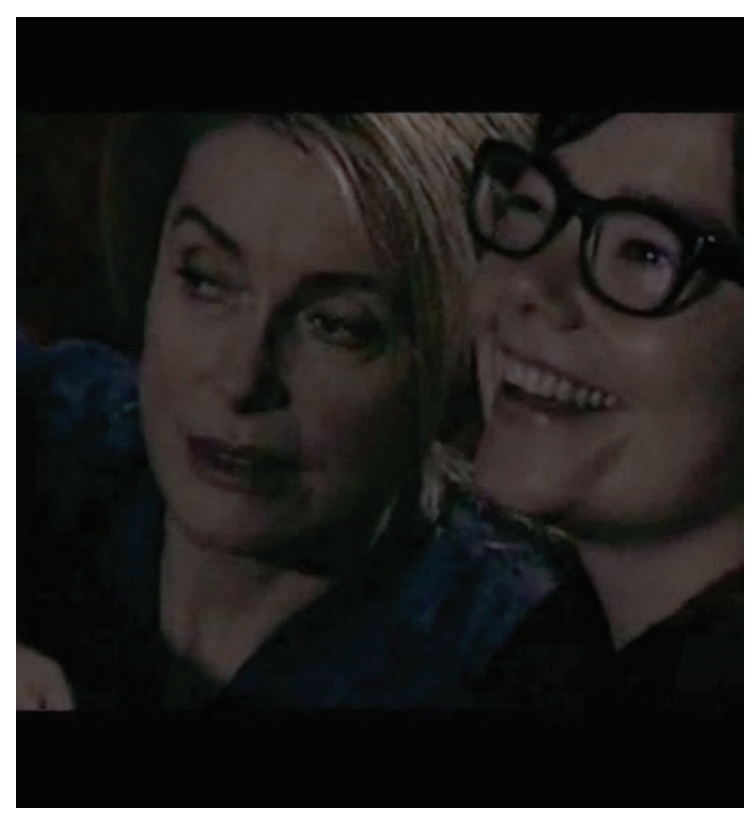

[Figura 2] Screenshot de Kathy e Selma assistindo a um musical no cinema.

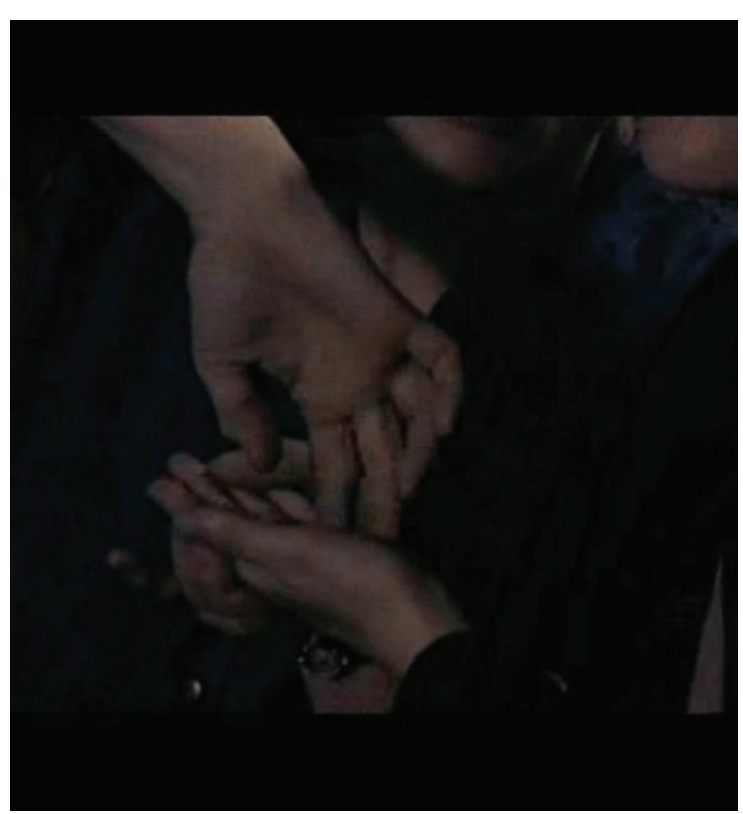

[Figura 3] Kathy recompõe os passos de dança com os dedos na palma de Selma. 


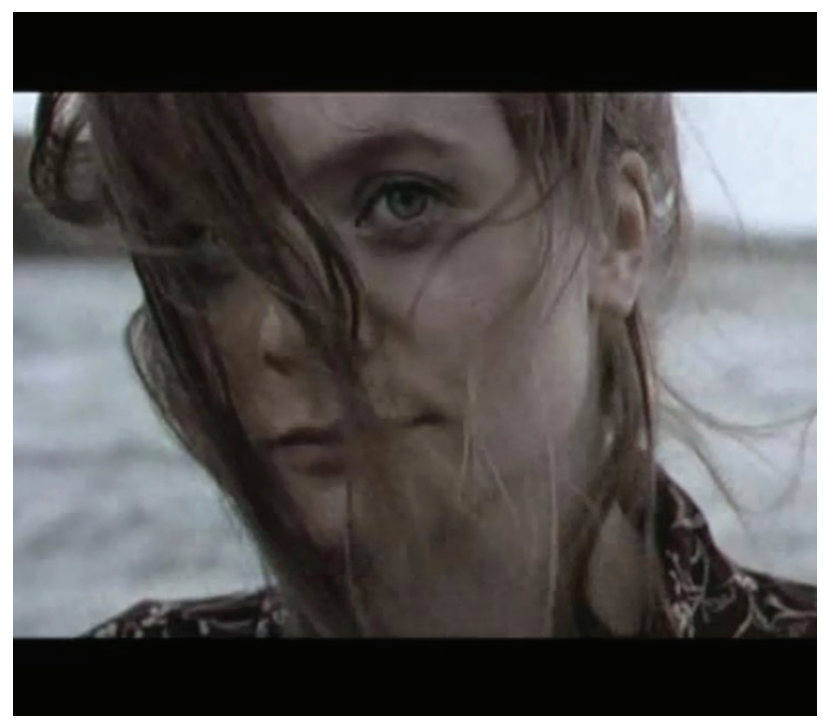

[Figura 4] Primeiríssimo plano, normal, 3/4. Delicadeza e força se amalgamam na expressão de Bess, permite analogia com expressividade de Inger em Ordet.

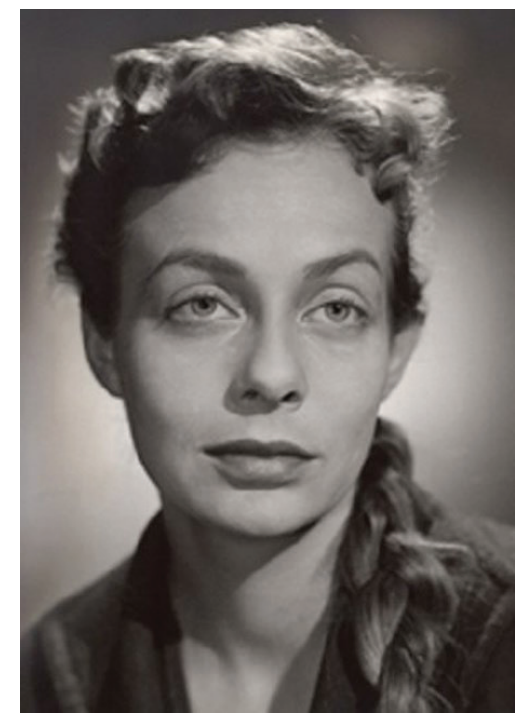

[Figura 5] Foto de Birgitte Federspiel, que interpreta Inger, expressividade do olhar da atriz conjuga força e delicadesa, assim como a personagem Bess.
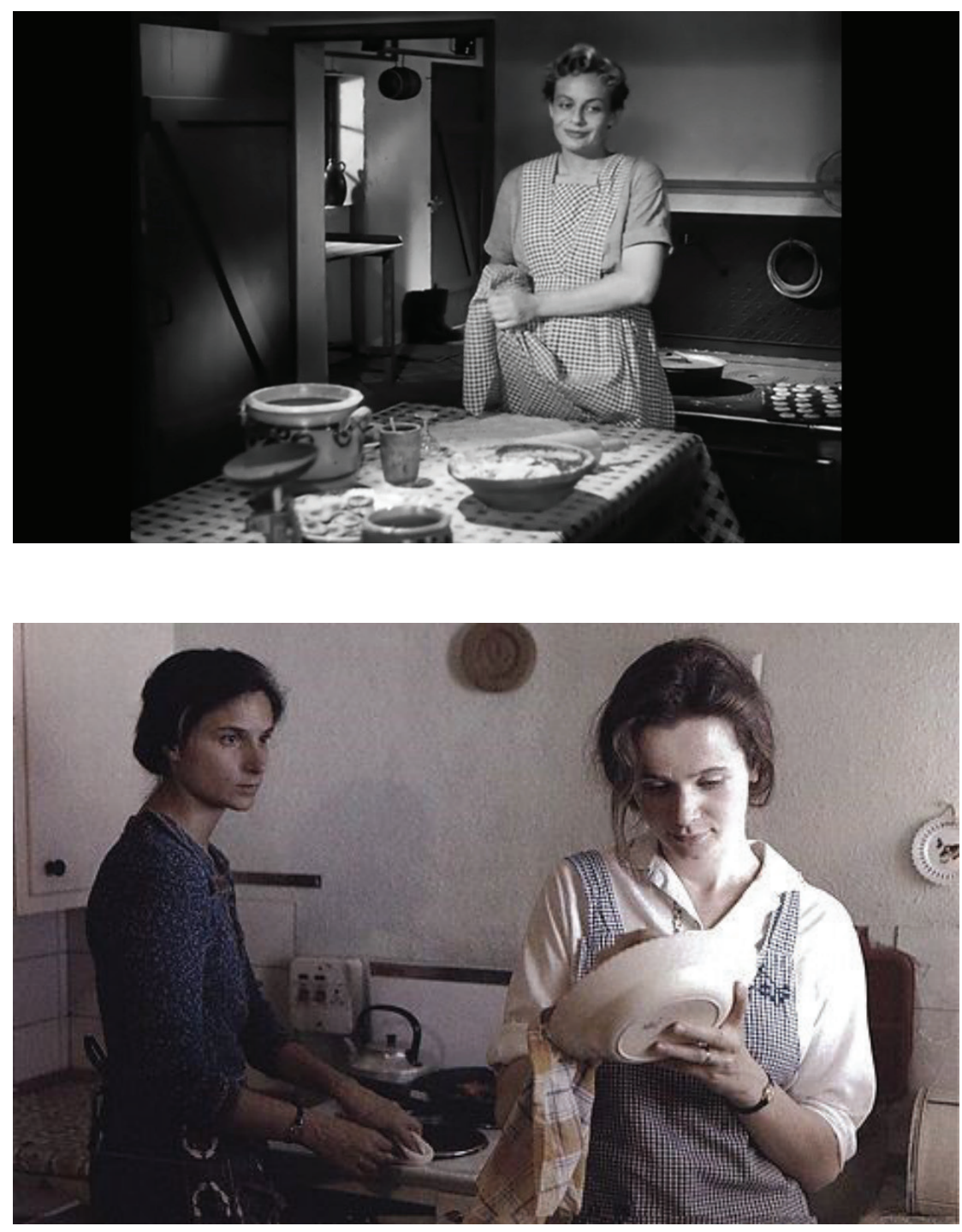

[Figura 6] Plano Americano, normal, 3/4. Inger em cena doméstica em Ordet, ambientação e figurino permitem analogias estéticas com Bess de Breaking the waves.

[Figura 7] Meio primeiro plano, normal, frontal. Bess em cena doméstica, ambientação e figurino permitem analogias estéticas com a personagem Inger. 


\section{Referências Bibliográficas}

BIRZACHE, Alina G. The holy fool in European cinema. London and Newyork: Routledge, 2016.

COLI, Jorge. Sexo, luto e martírio. Folha de S. Paulo, São Paulo Coluna ponto de Fuga, Caderno mais, coluna Ponto de fuga, 25/10/2009. Disponível em: <https://www1.folha.uol.com.br/fsp/mais/fs2510200904.htm>. Acessado 19/12/2019

FURUITI, Edna. A imagem fundamental e o traumático: possibilidade de sentido em Festa de família e na trilogia Coração de ouro. São Paulo, Mestrado, Universidade de São Paulo/ Escola de Comunicação e Artes da USP, 2002.

GERACE, José Rodrigues das Neves. O cinema de Lars Von Trier: dogmatismo e subversão. Belo Horizonte, Mestrado, Universidade Federal de Minas Gerais/Escola de Belas Artes, 2006.

KRUCER, Patrícia de Almeida. Penetrando o Éden: Anticristo, de Lars von Trier, à luz de Brecht, Strindberg e outros elementos inquietantes. São Paulo, Doutorado, Universidade de São Paulo / Programa de pós-graduação em estudos linguísticos e literários em inglês da Faculdade de Filosofia, Letras e Ciências Humanas, 2016.

LUMHOLDT, Jan. Lars von Trier Interviews. Mississippi: The University Press of Mississippi, 2003.

PIERUCCI, Antônio Flávio. O desencantamento do mundo: todos os passos do conceito em Max Weber. São Paulo: Editora 34 , 2013.

TRIER, Lars von. Breaking the waves. United Kingdon: faber and faber, 1996.

WEBER, Max, 1904. A ética protestante e o 'espírito' do capitalismo. São Paulo: Companhia das letras, 2004. 